\title{
COMPARISON OF MECHANICAL TESTS ON THE DYE-3, GREENLAND ICE CORE AND ARTIFICIAL LABORATORY ICE
}

\author{
by
}

\author{
H. SHoji and C. C. Langway, JR
}

Ice Core Laboratory, Department of Geological Sciences, State University of New York at Buffalo, 4240 Ridge Lea Road, Amherst, New York 14226, USA

The horizontal velocity of a thick ice sheet is maximum at the surface and decreases with increasing depth. The horizontal velocity profile at a given location differs from another location depending upon the in situ stress and temperature conditions and the changing but distinctive physical and chemical character of the ice profile. The main property changes that influence the behavior of horizontal ice flow include chemical impurity concentration levels (both solid and dissolved components) and c-axis orientation. Shoji and Langway (1984) calaculated the velocity profiles for both the Camp Century and Dye-3 Greeland location by taking into consideration possible enhancement factor variations over the profiles. This analysis was compared with the theoretical and experimental strain rate data obtained for laboratory ice at the same stress and temperature levels. This study indicated that the largest horizontal velocity component is the result of a highly enhanced shear deformation zone, a few hundred meters thick existing at the base of the ice sheet.

Detailed mechanical property measurements were made on the Dye-3, Greenland $\left(65^{\circ} 12^{\prime} \mathrm{N}, 43^{\circ} 47^{\prime} \mathrm{W}\right)$ ice core over its entire profile $(2037 \mathrm{~m})$ as shown in Table 1. Tests were made in uniaxial compression under constant crosshead speed (specimen size, about $2.5 \times 2.5$ $x, \mathrm{~cm}$ ) and simple shear under constant load (specimen size, about $2 \times 2 \times 3 \mathrm{~cm}$ ), with test temperature held constant between -12 and $-17^{\circ} \mathrm{C}$. The experimental results were analyzed by using the power law creep equation with enhancement factor terms. Stress exponent values of $2.7,3.2,2.9$ were obtained for specimens (oriented so as to have the maximum resolved sheer stress in the horizontal plane of the ice core) from depths of $235 \mathrm{~m}$ and $247 \mathrm{~m} ; 1814 \mathrm{~m}$ and $1816 \mathrm{~m}$; and $2021 \mathrm{~m}$ respectively. These values are close to those obtained earlier (Barnes and others 1971) for artificial laboratory polycrystalline ice. The enhancement factor values for horizontal shear deformation, changed with depth and correlated well with the c-axis profile of Herron S and others (1981). Above the $800 \mathrm{~m}$ depth, the enhancement factor value ranges between about 0.5 and 1. Below the $800 \mathrm{~m}$ depth, the enhancement factor increases up to about 3 near the Holocene/Wisconsin transition depth (about $1786 \mathrm{~m}$ )

Between the $1786 \mathrm{~m}$ and $2037 \mathrm{~m}$ depths, the enhancement factor values ranged from 6 to 20 with an average value of about 10 . The c-axis orientations were obtained by ultrasonic wave velocity measurements over the 1786 to $2037 \mathrm{~m}$ interval. The results of 114 samples measurements showed that the ice has a single maximum fabric pattern from $1786 \mathrm{~m}$ through to the bottom with variations in the strength of c-axis concentrations. Chemical impurity levels of $\mathrm{NO}_{3}{ }^{-}, \mathrm{SO}_{4}{ }^{2-}$ and $\mathrm{Cl}^{-}$also vary over this depth interval but on average the Wisconsin ice has 2 to 4 times more chemical impurities than does the Holocene ice (Herron and Langway 1985; Finkel and Langway 1985). Additional experiments on the Dye-3 core with different impurity levels showed that impurity enhancement factors should be less than 2 (enhancement factor $=$ fabric enhancement factor $x$ impurity enhancement factor). We conclude, therefore, that the fabric enhancement factor is of primary
TABLE 1. SAMPLE DEPTHS FOR UNIAXIAL COMPRESSION AND SIMPLE SHEAR TESTS ON THE DYE-3, GREENLAND ICE CORE.

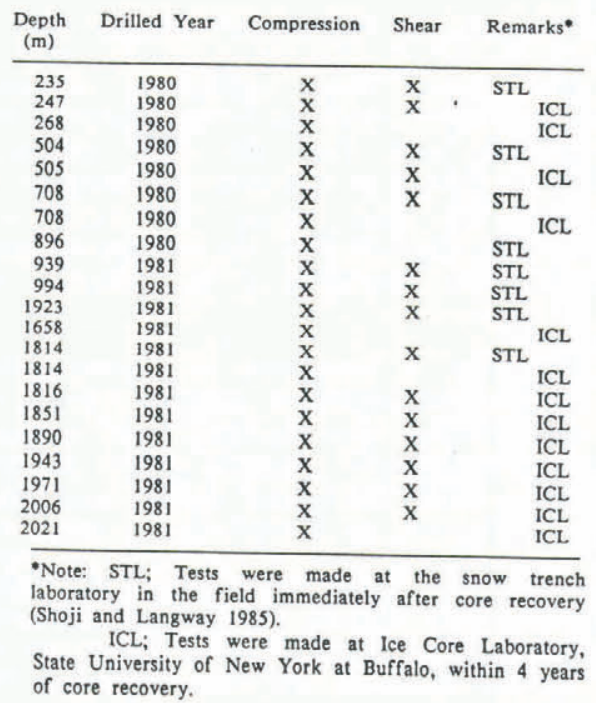

significance for the high enhancement factor value of Wisconsin and basal silty ice. The strong c-axis orientations on the same ice implies a high anisotropy of the mechanical properties which was experimentally confirmed.

\section{REFERENCES}

Shoji H, Langway C C Jr 1984 Flow behavior of basal ice as related to modeling considerations. Annals of Glaciology 5: 141-148

Shoji H, Langway C C Jr 1985 Mechanical properties of fresh ice core from Dye 3, Greenland. Geophysical Monograph, American Geophysical Union 33: 39-48

Barnes P, Tabor D, Walker J C F 1971 The friction and creep of polycrystalline ice. Proceedings of the Royal Society of London A 324(1557): 127-155

Finkel R C, Langway C C Jr 1985 Global and local influences on the chemical composition of snowfall at Dye 3, Greenland: the record between $10 \mathrm{ka} \mathrm{B.P.} \mathrm{and} 40 \mathrm{ka}$ B.P. Earth and Planetary Science Letters 73: 196-206

Herron S L, Langway C C Jr, Brugger K A 1985 Ultrasonic velocities and crystalline anisotropy in the ice core from Dye 3, Greenland. Geophysical Monograph, American Geophysical Union 33: 23-31

Herron M M, Langway C C Jr 1985 Chloride, nitrate and sulfate in the Dye 3 and Camp Century, Greenland ice cores. Geophysical Monograph. American Geophysical Union 33: 77-84 